\title{
The Existing Problems and the Solution Strategy in the Basic Music Education in Our Country
}

\author{
Lu Liu \\ School of music, Zhengzhou University, Zhengzhou, 450052,China
}

Keywords: Basic music education, Problems, Solution strategy

\begin{abstract}
With the development of the social economy, music art in our country has gained some impressive achievements, but there still exist some drawbacks behind the glorious accomplishments. They include the poor understanding about the value of the music itself which only remains on the superficial level of interests or tools, the failure of manifesting national characteristics of music in the education areas, leaders' attaching no great importance to the music teaching in the schools and the failure of the relationship management between quality education and music education.

With the improvement of people's living standard, they have stronger desire for the pursuit in spiritual level especially the music art. The enterprise of basic music education in our country has grown mature gradually with the strong support and concern from the country and the society and under the long-term effort of so many music teachers. As time passes, the development direction of global basic education keeps changing. As the growing trend of globalization requires the cooperation of the basic music education enterprise, the basic music education needs some adjustment and change to adapt to the requirement of the smooth conduction of quality education.
\end{abstract}

\section{The Status Quo of the Basic Music Education in Our Country}

(1).The Unbalanced Development of the Basic Music Education

From the point of geography, the development of basic music education in our country is not balanced. In some developed areas where the posts of music teachers are basically complete, relevant music teachers can be assigned to carry out the teaching of basic music toward the students. However, as most places in some underdeveloped areas are the remote mountains and villages, they are not the choice of the majority music teachers. Music teaching cannot enter the classroom teaching due to the lack and teacher resources, the backward or even insufficient teaching equipments. It leads to the bad music teaching in the underdeveloped areas and fails to guarantee the favorable conditions for the students to study basic music. The regional disparity lowers the popularity of basic music education in our country, causes the unbalanced development of the basic music education as well as violates the overall education spirit of the quality education.

(2) The Poor Understanding about the Value of Basic Music Itself

Most people's understanding toward the value of the basic music itself only remains on its superficial meaning: the social interests of music and its impact as tools. When we refer to music teaching, teachers can only think about the most basic class practices such as singing and dancing. In the thinking mode of most music teachers, the classroom teaching goal of music teaching is to teach the students to sing and dance. Therefore, in the classroom teaching of basic music, teachers only emphasize the teaching of the technical aspect in teaching and consequently ignore the most fundamental and important role of music as an art and a discipline, which makes the teaching of basic music go against the real teaching goal and philosophy. The existing drawback in the modern system of music education is manifested mainly in the wrong idea of the poor understanding of the music value. Therefore, it is imperative to reform the music education system so that the classroom teaching for the students can be conducted better.

(3) The Lack of National Interests in Music

In our country, the study and research about the music started from the schools songs aboard. After the foundation of China, influenced by the social situation at that time, the music education in our country emphasized more on the imitation of the former Soviet Union to a large extent. After reform and openness, we learned music technology from many advanced countries in terms of 
music education, but the original excellent music culture has been more weakened due to our blind study of the western music technology and method. As a result, we are more inclined to the foreign culture as to the choice of the music teaching contents and teaching method, turning a blind eye to the traditional music culture in our country. It hinders the further development of national music.

(4) The School Leaders' Ignorance toward Music Education

From the point of teaching management, the school leaders and management departments attach no great importance to the role of music education in the overall education of the students. Although the reform of modern education system changes the long-term teaching methods, the future of the students still lies upon the result of the college entrance examination. Therefore, most people belittle the role and effect of music education, which causes an obvious position of music among the other disciplines in the schools. In some schools, there is no plan of the opening of basic music education in the schools' curriculum provision, while in others, even the music courses have been set up, they are still occupied by other main examination subjects. It makes the basic music education exist in name only and fails to embody the value of basic music course. Because of the indifference toward basic music, many music teachers can not realize their self-worth, so they gradually lose their interest in music and turn to other professions. It is the loss of faculty for the music education industry, whose appearance becomes the severe impediment to the development of music discipline.

(5)The Ambiguous Relationship between Music Education and Quality Education

With the continued progress of the modern education system reform, more and more people connect the art education such as music with the quality education. There are many versions about the relationship between music education and quality education: 1) music education is quality education;2) music education is the foundation for the development of quality education; 3)music education can replace quality education 4) music education is incompatible with quality education. These views fail to really realize the value of music education itself and ignore the real function of basic music education.

\section{How to Solve the Problems of Basic Music Education in Our Country}

At present stage, the existing problems in the basic music education in our country are not only caused by people's wrong ideology, but also the imperfection of the education system. There are two solutions: through the macroscopic and microscopic view. From the macroscopic view which is the will of the state. Government solves it through the deepening of education system reform which is the external cause of the solution. From the microscopic view which is subjective initiative, the school solves the problems of music education through the reform of the school-running method which is the internal cause of the solution. The unification of the external and internal cause is the main channel to solve the existing problems of the basic education in our country.

(1)The Solution from the Macroscopic View

1. The Change of the Employment Idea for the College Graduates

Since the colleges and universities increase the enrollment, it puts unprecedented pressure on the employment of the students. Along with the increasing population of the graduates, college education turns into universal education. Thus the phenomenon results in the oversupply of the graduates. But tracing back to the primary cause, we find that the incorrect employment idea of the graduates is the main reason. We take Heilongjiang province as an example. As most graduates choose to develop their career in Harbin, then some remote regions are left without anybody to care for. Influenced by the employment idea, most graduates locate their working place in the developed areas, so the employment figure in the underdeveloped areas is few. For the basic music education, there exists an extreme imbalance in the basic music education among the regions because of the limitation of the faculty, abundant faculty in the developed areas and the short-handed faculty in the underdeveloped areas. Therefore, in order to change the imperfection of the current basic music education, when the colleges are conducting the occupational guidance toward the students, they should respond to the call, pass the spirit of selfless contribution, support the economic development in the underdeveloped areas, lead the students to sacrifice their 'light' and 'heat' and 
make contribution for the music education in the underdeveloped areas.

2. Strengthening the Effort to Reform the Education System

The new round of education system reform is conducted to respond to the international situation. It requires music teachers' joining in the reform of education courses positively, relevant management departments' formulation of the training program of education course, the increase of the number of the training for the course reform of the music teachers and the improvement of the training quality of the music teachers. Through related investigation, it is found that most music teachers do not participate in the training for the course reform of music education, which makes the music teachers not familiar with the music education course under the background of new curriculum reform. Therefore, in light of this situation, related management departments should supervise the training for the course reform of the music education to make music teachers join the education training positively, lift individual teaching abilities and guarantee the systemization and regulation of the training.

3. Building a Harmonious Relationship between Ethnic Music Culture and Multicultural Music

Under the historical background of information explosion, internet culture is gradually universal. With the increase of various countries' connection of politics, economy and culture, the trend of globalization is getting more and more obvious. Under this social background, there are more channels for us to gain resources with the methods being easier and more convenient. Therefore, while we get more familiar with the resources outside the world, we concern less about our own resources. When music teachers proceed the music education toward the students, they should emphasize the traditional ethic music culture in our country, carry out appropriate innovation on the basis of tradition inheritance, merge music with the music culture in other countries and manifest the characteristics of traditional music culture in our country. If there is no innovation, the trend of the music development will be global assimilation. Also the uniqueness of music culture of each country will be gone. The national one is the international one, so music teachers should respect the ethnic music culture in our country and understand the multicultural music. Under specific situations of teaching, music teachers should incorporate the unique music culture owned by their regions into the music teaching.

4. The Imperfection of the Evaluation System of Modern Education

The education system should keep up with the times and get reformation for the smooth process of modern education system reform. Some provinces have brought music into the selective subjects in the college entrance examinations. After implemented for a long time, it has clear effects and is applauded by most people. Also we can guide people's ideology to make them attach importance to basic music education, which is also conducive to the reformation of education system.

1.A Correct Understanding about the Relationship between Music Education and Quality Education

With the deepening of theoretical research, we have a brand new view toward the relationship between music education and quality education. The goal of quality education is based on the students' development, so the most important thing is the development of the students. Quality education aims at promoting the students' individuality to gain development which should be sustained and comprehensive. Regarding students as the foremost thing is the cultivation of the students' world outlook, outlook on life and values and the respect toward ethics and behaviors. In total, quality education is directed to all the students and is the education system which focuses on the comprehensive development of the students. Music education, a component of quality education is also the main means to implement quality education. Therefore, music education and quality education share the same goal which is to promote the overall development of the students better.

(2) Solving the Problems from the Microscopic View

1. Elevating the Self-Quality of the Music Teachers

Schools should emphasize the training of music quality for the music teachers, improve their teaching skills and expand their professional skills of teaching. On the basis of guaranteeing their salary, the music teachers should be conducted with severe requirements and training to stir up their enthusiasm, set up their correct consciousness of lifelong learning, strengthen their professional 
skills as well as increase the education level of music.

2. Enriching the Cultural Life of the Students during the Extracurricular Time

The spare-time life of the students, as a part of students' learning at school, is also a unique way to embody the schools' teaching features. For example, the schools can set apart the spare time and let them have after-class activities. When the students are having after-class activities, the schools can play some cheerful music to let the students play under the background of music. During the noon break, they can play some melodious piano music, so the brains of the students can get a short relax and adjustment.

These methods of music influence are all meaningful basic music education to the students. These methods cultivate the students' comprehensive ability, increase their quality of music culture. The students gain healthy development physically and mentally and also their after-class activities are enriched. The schools can organize some extracurricular activities such as the extracurricular music activities like music bonfire parties and then invite all the teachers and students to participate, which not only enriches the campus culture life of all teachers and students, but also enhances the relationship between teachers and students. This shows the overall spiritual core of the schools.

3. Making preparations for the Brand New System of College Entrance Examinations

The college entrance examination reform has conducted the tentative experiment in some provinces, so it is possible for the policy of music as the selective subject of college entrance examination to be brought into the college entrance examination system. In order to deal with the reform of the system better, music teachers should respond to it actively to make sure that selective subjects can play a positive role in the college entrance examinations.

4. Changing the School-running Characteristics and Manifesting the School Features

Schools should attach great importance to the school-running characteristics, because the standard of the teaching quality in schools is not only the graduation rate of students, the school-running characteristics of the schools is also one of the standards to measure the teaching quality of the students. As most schools regard 'increasing the graduation rate' as the school-running goal, they have deviated from the route of quality education due to the unilateral pursuit of graduation rate. The school-running method of dividing students through grades in terms of faculty to look after the special student groups is the bad behavior for it sacrifices the graduation ideal of most students to gain its own economic interests. The research shows that there are no inferior students in the schools and every student has its own advantage and strong point. So the schools should respect and pay attention to the specialty of each student. The so-called school-running characteristic is not measured by dividing the students through grades, but to adopt different education methods toward different students in order to promote the comprehensive development of the students. The students-centered method of school-running is the true manifestation of the school-running characteristics in schools.

\section{Conclusion}

Through the analysis of the status quo of the basic music education in our country, we know that the cause of this situation is not only the existing flaw in the education system, but also people's ignorance toward the importance of music education. Therefore, in order to change the status quo of basic music education in our country, we should conclude the main measures for the solution through the analysis and thinking from the macroscopic and microscopic view. Music has some facilitation on the emotional cultivation and humanity attainment of the students. Music education, as an integral part of quality education and the selective discipline in the college entrance examinations, should be emphasized by the government, schools, teachers and the students themselves. The development of basic music education enterprise is a long-term process during which the concern and assistance from the society are needed. The healthy development of basic music education is the basis of the school-running characteristics, the guarantee for the students to improve their own comprehensive quality and even the important condition for the advance of the music enterprise in our country. 


\section{References}

[1] Zhao Dagang. The Existing Problems and Solution Strategy of the Basic Music Education in Our Country[J] The Grand Stage,2012(2).

[2] Taohong. The Existing Problems and Strategy in College Music Education[J] The Education Exploration, 2011(12).

[3] Tu Qinping. The Status Quo Analysis and the Countermeasures about the Modern Teaching of Higher Music Education[J].Hundreds Schools in Arts,2010,26(4)

[4] Xu Honghshuai.The Current Situation of Implementation and Basic Strategy of the Music Education Course Reform in Our Country[J].Journal of Central Music Conservatory, 2011(4).

[5] Yang Qiuyi. The Goal of Music Education[J]. Chinese Music Education, 2012(4). 